\title{
Assessing the Challenges and Opportunities in the Oil and Gas Industry
}

\author{
Emmanuel Tsegha \\ Civil Engineering Department, \\ Federal Polytechnic, Bauchi-Nigeria
}

Doi:10.5901/ajis.2013.v2n12p129

\begin{abstract}
It is a huge paradox, a curious irony so difficult to swallow, not to mention digesting, that Nigeria as the world's 6th largest oil producer can barely meet its local needs of fuel supply. This strange phenomenon begets a litany of wild and unhelpful ramifications on the nation's economy. Talk of capital flight, talk of poor value addition to our physical resources, think about scandalous fuel subsidy outlay among others. This paper is an overview of operations in the oil and gas industry vis-à-vis these challenges, seeks to highlight the opportunities available, and the need to pursue an aggressive developmental strategy in this sector. While the world is now focusing on natural gas as a viable alternative to crude oil, there is gross, dismal under-utilisation of same and outright wastage via flaring, in Nigeria. It is also a clarion call on stakeholders to make this all-important sector an optimal, intangible wealth creator.
\end{abstract}

Keywords: Intangible wealth, Associated gas, Liquefaction, Greener vehicle, Social capital.

\section{Introduction}

There's no gainsaying the fact that oil and gas are the lifeblood of Nigeria's economy and elsewhere, for now and many years to come. As we are aware, the petroleum industry is a major contributor to the National Gross Domestic Product (GDP) as well as the major foreign exchange earner, accounting for about $80 \%$ of National Revenue and over $90 \%$ of the nation's foreign exchange earnings. This fact was stated by no other than former double president Olusegun Obasanjo while addressing the $25^{\text {th }}$ Society of Petroleum Engineers (SPE) Annual Conference and Exhibition in 2003.

We are told that current crude oil production is little over 2 million barrels per day (bpd). For 55 years now production has been on-going, having begun production of about 5000 bpd in 1957 near Oloibiri, Rivers State.

According to the Organization of Petroleum Exporting Countries (OPEC), Nigeria has an estimated 37 billion barrels of oil reserves. Most of the country's proven oil and gas reserves are concentrated in the Niger Delta region.

Vision 20:2020 envisages that oil reserves will increase to 40 billion barrels with discovery of new oil wells and daily production from current levels to about 4 million bpd.

\section{Oil Industry Operations}

Operations in the oil industry are broadly divided into three categories namely, Upstream, Midstream and Downstream processes. 


\subsection{Upstream Sector Operations}

This is the sector that deals with exploration (searching), finding and production of crude oil and natural gas.

There are land-based operations, usually referred to as onshore and operations over water, usually referred to as offshore.

International Oil Companies (IOC's), otherwise known as Multinational Oil Companies (MOC's) are the main operators in the Nigerian Upstream Sector. They include Shell, ExxonMobil, Chevron, Total and Agip.

In this process the Federal Government of Nigeria (FGN), through the Nigerian National Petroleum Corporation (NNPC), act as the senior partner with the oil producing companies in what is called J oint Ventures (JV's).

The arm of NNPC that oversees the interest of FGN is the National Petroleum Investment Management Services (NAPIMS).

\subsection{Midstream Sector Operations}

This sector is a bridge between the upstream and the downstream sectors, and comprise of processes such as storage, transportation and marketing.

The crude oil produced is moved from the production spots to the ports for direct exportation or to the refineries for processing.

The sector provides for about $90 \%$ of Nigeria's exports.

\subsection{Downstream Sector Operations}

The activities in this sector include refining, transportation, storage, distribution and marketing of the refined products. NNPC is the dominant player here through its refineries and subsidiaries such as Pipelines and Products Marketing Company (PPMC).

There are other players here too who are classified as either major or independent marketers depending on the volume of product they handle.

\section{Oil Refining Capacity versus Domestic Demand}

According to 2010BP Statistical Energy Survey, the estimated daily demand for petroleum products in Nigeria is,

33 million litres of petrol, otherwise known as premium motor spirit (PMS),

18 million litres of diesel, that is automotive gas oil (AGO), and

10 million litres of dual purpose kerosene (DPK)

DPK is made up of aviation turbine kerosene (ATK) or Jet Al and household kerosene (HHK)

The survey states that the estimated amount of crude oil required daily for domestic refining that would satisfy this demand adequately should be about 530,000 bpd.

However, the nation's four refineries (all government-owned), with a combined installed refining capacity for 445,000 bpd could only process 360,000 bpd due to old age and poor Turn Around Maintenance (TAM). See Table 1.0 for the ages and installed capacities of the refineries.

The last ATM for these refineries is as follows:

Twin PortHarcourt Refinery, last had TAM in 1999 (14 years today)

Warri Refinery, last had TAM in 2004 (9years now)

Kaduna Refinery, last had Tam in 2008 (5years now)

But experts say that a fully functional refinery should undergo TAM every 2 years. 
Table 1: Installed Domestic Refining Capacity.

\begin{tabular}{|ll|c|c|}
\hline \multicolumn{1}{|c|}{ Refinery } & Year of Construction & Installed Capacity (bpd) \\
\hline i. & PortHarcourt Refinery & $1965(48$ years old $)$ & 60,000 \\
\hline ii. & Warri Refinery & $1978(35$ years old $)$ & 125,000 \\
\hline iii. & Kaduna Refinery & 1980 (33 years old $)$ & 110,000 \\
\hline iv. Eleme (New Port Harcourt) Refinery & 1989 ( 24 years old $)$ & 150,000 \\
\hline Total installed capacity & 445,000 \\
\hline
\end{tabular}

\section{Source: NNPC}

This development has led to the current important contribution (especially, PMS) ranging from 60$80 \%$. Even if the refineries were operating at full capacities, it is clear that the situation would not have been any better.

For over two decades now this has provided an excuse for the government to import fuel at higher prices and to use that as reason for claiming huge subsidies which might not have arisen if the refineries were adequate and functioning as they should.

It will be recalled that recently, the National Assembly House Committee probing fuel subsidy scandal got enmeshed in bribe-taking.

It is interesting to recall that on Tuesday, $21^{\text {st }}$ March, 1989, while commissioning the fourth refinery at Eleme (described by Omoifo as the " $4^{\text {th }}$ wonder"), the then president, General Ibrahim Babangida declared that the nation will have,

"a potential surplus of approximately 100,000 bpd of refining capacity for the export market, making Nigeria a prominent member of the league of refined petroleum products exporting countries."

This statement pre-supposes that, with the $4^{\text {th }}$ refinery coming on stream the nation should have been, not only self-sufficient in petroleum products, but also be exporting these products.

Today, more than two decades thenceforth, national deficiency in refined petroleum products still persists, and not for a singular intermittent occasion did it ever abate nor cease.

The argument on the lips of several well-meaning Nigerians has always been that the nation needs more refineries, functional ones at that, in order to reverse this unhelpful trend of national deficiency in refined petroleum products to a position of national prosperity. National prosperity by way of more employment for citizens, more export earnings, immense varieties of petrochemical products, limiting or outright cessation of subsidy outlay.

Talk about a chain of value addition to a God-given tangible asset.

Late Prince Aret Adams ( former Managing Director of NNPC), late Professor Sam Aluko chorused this argument to their last days, that it is cheaper and more beneficial to refine crude oil locally and export the refined products to fetch more revenue.

In buttressing this argument, Aluko (2003) went citing relevant examples two of which are;

i. "Rotterdam alone has eight refineries, which is not more than the size of Akure." Rotterdam is the capital city of Holland.

ii. "Singapore, a country of not up to 4 million inhabitants, with zero natural resources, no oil, has three refineries."

"This country ought to have about 20 refineries," he lamented. The pertinent question is why government is lukewarm about building new refinery(ies) and is equally not enthusiastic in encouraging the establishment of private ones.

In 2007 the Federal Government granted nine licenses to private investors to build refineries but the chairman of the Association of Private Refinery Owners of Nigeria, Justice Samuel Ilori has said that,

"federal government is responsible for frustrating the take-off of private refineries through 


\section{introduction of policies that are not favourable to the project."}

Now, Africa's richest man, Alhaji Aliko Dangote has just announced his decision to build a crude oil refinery in the country with 400,000 bpd (almost the combined total of the existing ones) by 2016.

To underscore the deep apprehension of stakeholders in this refining venture he has this to say, "that it is only mad businessmen that would want to invest in refinery," but that, "we are set to do that."

From what Dangote has said we can hazard a reasonable guess that policies are unpalatable or rather stringent for the prospective entrepreneurs.

\section{The Petroleum Industry Bill (PIB)}

This is a proposed legislation by the FGN to replace existing Petroleum Act of 1969. Through this bill, government is seeking to set out a new legal, regulatory and fiscal framework for the entire oil and gas industry.

The PIB was first drafted in 2003 during the tenure of President Olusegun Obasanjo, again presented to the National Assembly in 2008 by the late President Umaru Yar'adua but which did not scale through.

The current one (a 224-page affair) was drafted and re-presented in 2012 by President Goodluck Jonathan.

Debate on the bill is currently on-going in the National Assembly.

The PIB is protracted and contentious because there are so many vested interests in the oil and gas sector that are not comfortable with the passage of the bill as presently drafted.

It is hoped that those conflicting interests are amicably ironed out and the bill passed and enacted to usher in a new era in the oil and gas industry.

An era of more value addition to crude oil, an era of domestic self-sufficiency and exports in petroleum products, an era of private refineries etc.

\section{Improving Energy Security by Enhanced Utilization of Natural Gas}

Natural gas, a hydrocarbon (i.e a chemical made up of two elements, hydrogen and carbon) exist in underground reservoirs either on its own as free gas (non-associated gas) or in union with crude oil (associated gas).

It is composed of butane $\left(\mathrm{C}_{4} \mathrm{H}_{10}\right)$, ethane $\left(\mathrm{C}_{2} \mathrm{H}_{6}\right)$, propane $\left(\mathrm{C}_{3} \mathrm{H}_{8}\right)$ and methane $\left(\mathrm{CH}_{4}\right)$, with methane being the dominant component.

Due to environmental concerns and other complexities surrounding the production and use of crude oil as an energy source, the world is shifting emphasis from oil to gas as alternative energy source.

Nigeria cannot be left out, more so given her abundant natural gas reserves. Experts in the petroleum industry in Nigeria have told us that the nation is blessed with over 100 trillion standard cubic feet (scf) of natural gas reserves, which is equivalent to three times Nigeria's crude oil reserves. The gas reserves is about equally distributed between the two, associated and nonassociated categories, they say.

But it is clear that gas utilization has not been optimized, it is far from occupying its appropriate level in the nation's energy mix, both domestically and internationally.

Aside underplaying the potentials of natural gas, there exist a continual flaring (burning away) of this physical resource at the oil wells.

Besides the huge financial loss to the nation that this represents, it constitutes a serious environmental hazard.

There is every need in harnessing this resource for economic development, and reducing 
wastage of associated gas by enunciating appropriate policies.

\section{Natural Gas Value Chain}

Natural gas is such a versatile fuel that can be used in various projects including the following:

i. As a residential fuel for cooking, heating and air-conditioning. Natural gas, as Liquefied Petroleum Gas (LPG) is used for domestic cooking. The two major elements that make up LPG are propane and butane, with butane more than propane, in proportion of about $4: 1$

ii. Power generation: Thermal Power Plants such as Afam, Sapele, Ughelli and Egbin Stations use natural gas for power generation.

iii. Industries: Natural gas is a source of feedstock (raw material) for various industries. It is used in the Ceramics and Glass Industry for firing kilns.

In agriculture it is an important raw material for nitrogenous fertilizer.

iv. Automotive industry: Compressed natural gas (CNG) is used as an alternative automotive fuel.

v. Export eanings: Natural gas is converted into liquid, known as liquefied natural gas (LNG), to enhance transportation over long distances. For example, to sell to places like Europe and America.

The author intends to delve a little into the last two items, (iv) and (v).

\section{Compressed Natural Gas (CNG)}

Nigeria's daily consumption of fuel (especially PMS) is on the rise and the country's refineries fall short of demand, resulting into imports of about $80 \%$. Trillions of naira are spent each year for this. With this scenario it will not be out of place shifting attention to alternative fuels such as natural gas, ethanol etc.

Given the abundant gas reserves, CNG offers a formidable alternative. It is more environmentally friendly than PMS and diesel- fired engines, and safer in the event of a

spill (Venkataraman, 2013).

Toyota Motor Company of Japan calls an NGV (Natural Gas Vehicle) a " greener vehicle." By greener vehicles they mean vehicles that are environmentally friendly and reduce pollution to the barest minimum when in operation.

It is also said that the running cost of NGV's are cheaper, with savings of up to $25-30 \%$ in fuel cost (NIPCO, 2013).

In 2007, the Nigerian Independent Petroleum Company (NIPCO) in partnership with Nigerian Gas Company (NGC) started the CNG business in the country.

Today (2013), 8 CNG stations and 3 conversion workshops operate in Benin, Edo State with over 1,500 vehicles currently running on CNG in the city.

According to the Managing Director of NIPCO, Mr. Venkataraman, "the CNG scheme offers dual option to users by providing flexibility of running a vehicle, either on CNG or petrol, by simply flicking a switch installed on the dashboard."

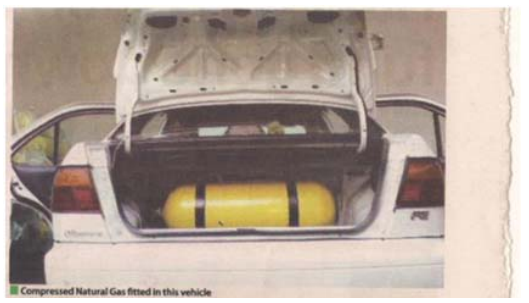


Dangote Group is also investing about N15 billion in CNG as alternative fuel for use by automotive industry in the country. The Group's 5000 trucks are being converted for dual usage (gas and diesel) presently.

It is hoped that more conversion centres and CNG filling stations will be established across the nation.

\section{Liquefied Natural Gas (LNG)}

Liquefied Natural Gas (LNG) is obtained when natural gas is cooled to a temperature of $-160^{\circ} \mathrm{C}$ to become liquid. The process is called liquefaction.

Liquefaction reduces the volume by about 600 times, making it more compact, occupying $1 / 600$ (600 times less) of its gaseous volume. Before liquefaction is done raw gas has to be conditioned, that is removable of impurities. 1980).

A liquefaction plant may consist of several parallel units called trains (Rogers \& Mayhew,

Liquefied gas is easier to transport over long distances. The long distances are across the oceans to destinations in Europe and America.

Transportation is by specially designed ships to receiving terminals, where it is pumped from the ship into storage tanks. When the gas is needed for usage, the LNG is warmed to convert back to its gaseous state by a process called degasification. Then it is distributed via pipelines to homes.

Transportation is a very important variable in the LNG business. Any LNG project must have an accompanying LNG fleet of those specially designed vessels.

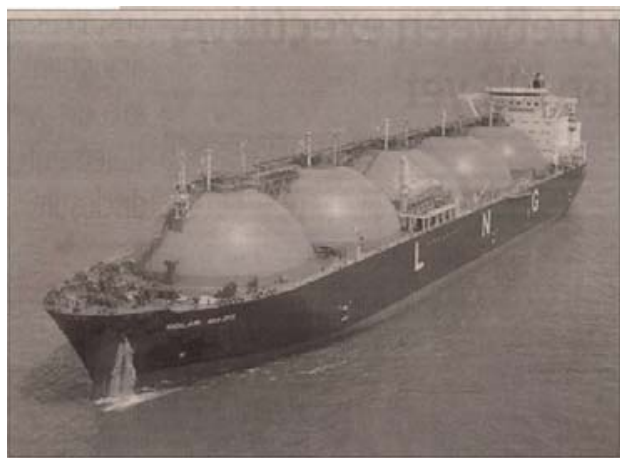

Liquefied Natural Gas (LNG) tanker

Nothing can be achieved without this because the product is only paid for when it arrives its destination intact. World demand for LNG is huge and growing.

World Bank estimates reveal that global demand for gas will outstrip oil by 2020 .

\section{The Nigeria LNG Project}

Though belated, the LNG seems to be the most ambitious project in the exploitation of the massive gas reserves.

There had not been any serious gas utilization plan until the inception of Nigerian LNG in 1989.

The LNG Ltd., located at Finima, Bonny Island, is jointly owned by NNPC (49\% share holding), Shell (25.6\%), Total (15\%) and Eni (10.4\%)

It has a subsidiary company, Bonny Gas Transport, that provides Transport (shipping) services to LNG (LNG website, 2013). Production which began with two trains in 1999 has now 
been expanded to six. But this project, laudable as it is, only scratches the surface of the challenges and opportunities available. We are still left with the bulk of gas waiting to be tapped and associated gas continues to be flared.

\section{Challenges and Proposed Recommendations}

\subsection{Fuel Imports Attendant upon Domestic Refining Deficit.}

There has been a repetition of well-meaning voices calling on government to build more refineries and/or create enabling conditions for private ones.

That call is again being repeated here

Intangible wealth is greater and more beneficial to the nation than tangible wealth. Tangible wealth is derived from raw materials (in this case, crude oil) export as against intangible wealth which is derived from finished products with added value. that,

In justifying air-fare hike, the CEO of Westlink Airlines, Capt. Ibrahim Mshelia has this to say,

"Domestic airfares will remain high so long as Nigeria does not refine its aviation fuel (Jet Al) locally."

In the absence of adequate, functional domestic refineries it is recommended that we contract- refine abroad what we cannot refine locally.

After all, we contract out abroad simple jobs such as ballot boxes, voting papers and the like.

It is also hoped that the PIB currently before the National Assembly will ensure that incentives are granted to allow for the development of private refineries alongside the existing ones

\subsection{Gas Flaring and Under- Utilization}

Continued gas flaring clearly underscores the under-development of the gas industry in Nigeria.

ExxonMobil (2003) has stated that, "the country stands to gain an estimated \$3billion a year when the gas currently being flared, is fully commoditized."

Oil exploration and production companies have to roll out programmes geared towards the reduction, if not total ending, of gas flaring.

- Greater domestic utilization of natural gas for power generation, industries and cooking would free petroleum for exports, free the diesel, petrol and household kerosene that otherwise would have been used.

- Use of natural gas for domestic cooking could also reduce the use of firewood and help halt deforestation and consequently desertification.

- There is every need to establish a $2^{\text {nd }}$ LNG plant to fully utilize the large volume of gas reserves for more exports.

\subsection{Security Challenges}

It is common knowledge that there exist security challenges in the Niger Delta, the epicentre of oil and gas operations.

Cases of militant attack on oil installations, oil theft (bunkering), attacking and killing of security operatives, and piracy abound.

While militant attack on oil installations in the region have slowed down due largely to the 2009 amnesty programmes, oil theft has continued unabated.

The JTF battling oil theft has confessed that, "we can't stop oil thieves," because the barons behind the crime are wealthy, influential and untouchable Nigerians. 
The involvement of this top politicians, military generals always make nonsense of the efforts of the task force.

Unless the government develops the necessary political will to go after such barons behind the menace, the problem of oil theft will persist.

\subsection{Social Capital}

Universal values such as hard work, high level of patriotism, high level of discipline, a sense of common good, transparency and trust-worthiness form what social scientists call social capital.

In Nigeria, unfortunately, this values are lacking or totally absent. The persistent menace of oil bunkering by people in authority can be explained solely on lack of this social capital.

And by extension, it is largely responsible for our developmental crisis.

Many nations of the world such as Japan, China, South Korea etc. have prospered above Nigeria, not because their citizens are more intelligent than Nigerians, but simply because they exhibit high levels of social capital.

May God help us to equally imbibe this culture?

It is not encumbered by geographic boundaries.

\section{References}

Aluko, S. (2003, August 17). Monetisation is a foolish policy. Sunday Punch. 33(1256),pp 4-7

ExxonMobil(2013, J anuary 8). Energy issues literacy series. Daily Trust. 31(18), pp21-32

NLNG website (2013). www.nlng.com Retrieved on J uly 17, 2013 from the URL.

Omoifo, I. (1989, April 3). The fourth wonder. The African Guardian. 4(13), p19

Rodgers G. F. amd Mayhew Y. R. (1980). Engineering Thermodynamics, Work and Heat Transfer ( ${ }^{\text {rd }}$ ed.), Longman Group Ltd. London.

Shosanya, M. (2013,April 19 ), The proposed Dangote refinery and Nigeria's economy. Daily Trust. $31(93$,$) p18$

Venkataraman, V. (2013, April 14). High hopes as Nigeria invests in alternative fuel for cars. Sunday Trust 7(41). p56 